\title{
PYRAZOLE BEARING MOLECULES AS BIOACTIVE SCAFFOLDS: A REVIEW
}

\author{
HIRA AZIZ ${ }^{1}$, AMEER FAWAD ZAHOOR ${ }^{1, *}$ AND SAJJAD AHMAD ${ }^{2}$ \\ ${ }^{I}$ Department of Chemistry, Government College University Faisalabad, Faisalabad-38000, Pakistan. \\ ${ }^{2}$ Department of Chemistry, University of Engineering and Technology, Faisalabad-38000, Pakistan.
}

\begin{abstract}
Pyrazole being a heterocyclic motif has secured an eccentric status in the field of medicinal chemistry. Pyrazole and its derivatives have tremendous biological applications like anti-cancer, anti-microbial, antiviral, antifungal, anti-inflammatory, analgesic, insecticidal etc. In this review, some recent developments have been reported for the synthesis of biologically active pyrazole based molecules having biological potential such as anti-SIRT1 and SIRT2, anti-FAAH, anti-NOSs, as liver $\mathrm{X}$ receptor partial agonist, $\mathrm{CB}_{2}$ receptor ligand and glucagon receptor antagonists.
\end{abstract}

Keywords: Anticancer activity, Antimicrobial activity, Anti-inflammatory/analgesic activity, Insecticidal activity, Anti-enzymatic, Pyrazole.

\section{INTRODUCTION}

Pyrazole is an important five membered aromatic heterocyclic moiety having two adjacent $N$ atoms and three carbon atoms [1,2]. Molecules carrying pyrazole moiety display a broad spectrum of pharmaceutical and biological applications such as anti-cancer, anti-inflammatory, anti-fungal, antibacterial, antiinsecticidal, analgesic, antiviral, anticonvulsant, anti-diabetic, antipyretic, antiarrhythmic, anti-depressant, anti-hyperglycemic, anti-oxidant, herbicidal etc [311]. Indeed, Phenazone was the first pyrazole which was commercially available as antipyretic agent [12]. Now the fascinating medicinal potential of pyrazole could be analyzed by the lists of drugs available in market such as; Celecoxib [13], Lonazolac [14], Mepirizole [15], Rimonabant [16], acomplia [17] Cimetidine [18], Fipronil [19], Dexacoxib [20], etc.

\section{Biological importance of pyrazole derivatives}

\section{Anticancer activity}

Globally, cancer is the second major cause of increasing mortality rate after cardiovascular diseases [21] despite many treatments such as chemotherapy [22 - 23]. Pyrazole ring containing drugs have made a unique space in field of medicinal chemistry in competition of other drugs for cancer treatment such as Crizotinib and Encorafinib [24 - 27]. In order to develop novel anti-cancer drugs, Cao and coworkers in 2016 reported the synthesis of pyrazole carboxamide derivative $\mathbf{1}$ as potential anticancer agents by inhibiting $\operatorname{MEK}\left(\mathrm{IC}_{50}=91 \mathrm{nM}\right.$ in comparison to reference drug U0126 with $\left.\mathrm{IC}_{50}=89 \mathrm{nM}\right)$. Compound 1 with EWD fluoro group at para position of ring B was found to be most potent pyrazole derivative also against $\mathrm{A} 549$ cell lines with $\mathrm{GI}_{50}=0.26 \pm$ $0.02 \mu \mathrm{M}$ in comparison to reference drug Gefitinib with $\mathrm{GI}_{50}=2.86 \pm 0.18 \mu \mathrm{M}$ (Figure 1) [28]. Reddy et al. in 2016 reported pyrazolecarboxamide derivatives 2 (Figure 1) as excellent anti-proliferative agent against MIAPaCa-2, MCF 7 and HeLa cell lines in comparison to Nocodazole as show in Table 1 [29].
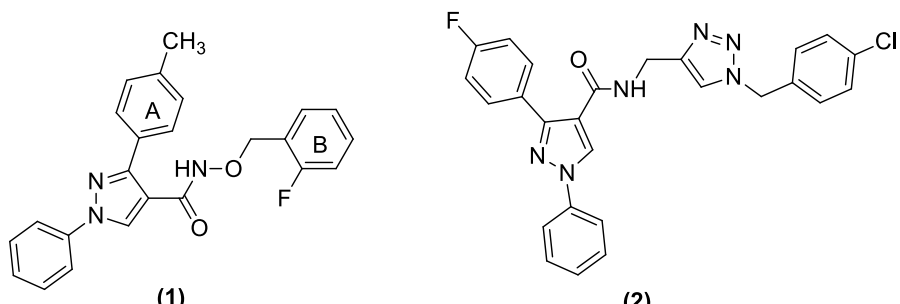

(1)

(2)

Figure 1. Structures of potent pyrazolecarboxamide derivatives $\mathbf{1}$ and $\mathbf{2}$.

Table 1. $\mathrm{GI}_{50}(\mu \mathrm{M})$ values of compound 2 against various cancer cell lines

\begin{tabular}{|l|c|c|c|}
\hline Compound & MIAPaCa-2 & MCF 7 & HeLa cell lines \\
\hline $\mathbf{2}$ & $0.28 \pm 0.03 \mu \mathrm{M}$ & $0.13 \pm 0.02 \mu \mathrm{M}$ & $0.21 \pm 0.04 \mu \mathrm{M}$ \\
\hline Nocodazole (control) & $0.95 \pm 0.013 \mu \mathrm{M}$ & $0.94 \pm 0.02 \mu \mathrm{M}$ & $0.81 \pm 0.01 \mu \mathrm{M}$ \\
\hline
\end{tabular}

Cinnamamide containing pyrazole derivatives were also found to be potent anti-proliferative agents as reported by Wang et al. in 2015. Improved antiproliferative activities were observed with the following increasing order of electron withdrawing groups at para position of phenyl ring A: 4- $\mathrm{CF}_{3}>\mathrm{NO}_{2}>4$ $\mathrm{OMe}>4-\mathrm{F}>4-\mathrm{Cl}>4-\mathrm{Br}>\mathrm{H}>4-\mathrm{Me}$. Moreover, the increase in activities by substitution on ring $\mathrm{B}$ was observed in the order as follows: 4-Me $<\mathrm{H}<4-\mathrm{Br}$. Among all compounds, compound $\mathbf{3}$ executed well as anti-proliferative agent (with $\mathrm{IC}_{50}(\mu \mathrm{M}$ ): $0.35 \mu \mathrm{M}$ for MCF-7, $0.62 \mu \mathrm{M}$ for A549, $0.57 \mu \mathrm{M}$ for B16-F10 and $1.02 \mu \mathrm{M}$ for tubulin inhibition) (Figure 2) [30]. Vaarla et al. in 2015 reported the synthesis of coumarin based thiazolylpyrazole derivatives with moderate to good anti-proliferative activities. Compound $\mathbf{4}$ was found to be better antiproliferative agent against HeLa cell lines with $\mathrm{IC}_{50}=5.75 \mu \mathrm{M}$ in comparison to reference drug Doxorubicin with $\mathrm{IC}_{50}=3.92 \mu \mathrm{M}$ (Figure 2) [31].
$\mathrm{Br}$<smiles>O=C(/C=C/c1ccc(C(F)(F)F)cc1)Nc1cc(-c2ccccc2)[nH]n1</smiles>

(3)<smiles>Cc1ccc(-c2nn(-c3csc(-c4cc5cc(Cl)cc(Cl)c5oc4=O)n3)cc2C=O)cc1</smiles>

Figure 2. Structures of selected compounds 3 and $\mathbf{4}$ with potent anticancer activity.

Kamal et al. in 2015 reported the synthesis of conjugated oxindole-pyrazole derivatives as potent microtubules binders/anticancer agents. Among all, compounds 5 (Figure 3 ) was found to be remarkable anti-proliferative agent with average $\mathrm{IC}_{50}=3 \mu \mathrm{M}$ against HeLa, A549, MCF7 and DU145 cancer cell lines in comparison to the reference drug Nocodazole with average $\mathrm{IC}_{50}=1.72 \mu \mathrm{M}$. It was observed that compound $\mathbf{5}\left(\mathrm{IC}_{50}=5.90 \pm 0.78 \mu \mathrm{M}\right)$ exhibited good inhibition of tubulin polymerization too. While nocodazole showed tubulin polymerization inhibition with $\mathrm{IC}_{50}=2.2 \pm 0.66 \mu \mathrm{M}[32]$.

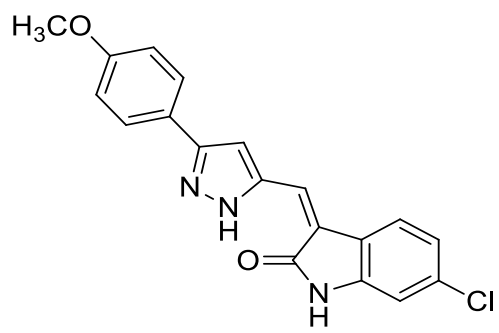

(5)

Figure 3. Oxindole-pyrazole derivative $\mathbf{5}$ as potent anticancer agent

In order to treat cancer with highly safe natural products, Zhang et al. in 2015 reported the synthesis of 23-hydroxybetulinic acid pyrazole derivatives via chemical modifications of triterpene derivatives. The results of MTT assay indicated the compound 6 (Figure 4) with acyl moiety in place of 23-OH group, pyrazole ring with free amine group and $\mathrm{C}-28$ with electron donating bulky groups as potent in vitro anti-proliferative candidate as shown in Table 2. 
Compound 6 was also suggested as best in vivo antitumor agent having 51.2 and $58.9 \%$ of inhibition against $\mathrm{H} 22$ liver cancer and B16 melanoma in mice as compared to parent compound HBA with 27.8 and $32.4 \%$ of inhibition, respectively [33]. Bertuzzi et al. in 2016 reported the synthesis of novel pyrazole derivatives containing lactam moiety and screened them against 5 cancer cell lines (MCF-7, MD-MB-231, HN13, V87MG and HeLa). The IC $_{50}$ values after $24 \mathrm{~h}(17.6-78.3 \mu \mathrm{M})$ and $72 \mathrm{~h}(10.6-33.5 \mu \mathrm{M})$ suggested that compound 7 (Figure 4) might be used as anti-proliferative agent [34].
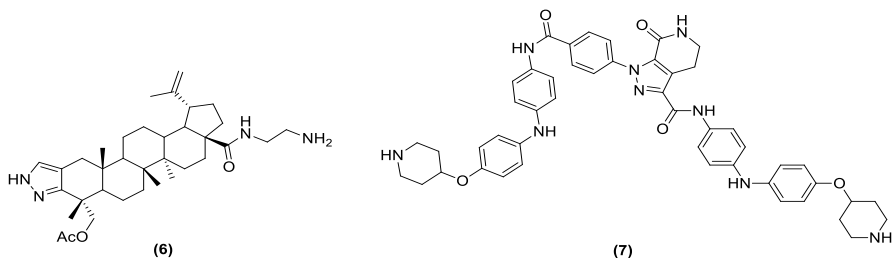

Figure 4. Structures of pyrazole derivatives 6 and 7 exhibiting good anticancer activities.

Table 2. Anti-proliferative activities $\left(\mathrm{IC}_{50} \pm \mathrm{SD}(\mu \mathrm{M})\right)$ of compound 6

\begin{tabular}{|l|c|c|c|c|c|}
\hline Compound & B-16 & SF-763 & HL-60 & BEL-7402 & HeLa \\
\hline $\mathbf{6}$ & $5.58 \pm 0.72$ & $6.13 \pm 0.90$ & $8.04 \pm 0.76$ & $8.12 \pm 0.41$ & $8.97 \pm 0.94$ \\
\hline Doxorubicin & $0.18 \pm 0.01$ & $0.16 \pm 0.03$ & $0.17 \pm 0.01$ & $0.22 \pm 0.02$ & $0.21 \pm 0.03$ \\
\hline
\end{tabular}

Inspired by the pharmaceutical importance of fused pyrazole ring with other heterocycles Wang et al. in 2016 reported the synthesis of tetrahydropyranopyrazole derivatives containing indolyl moieties. Among all, compound 8 (Figure 5) excellently inhibited the HGC-27 and PC-3 cell lines with $\mathrm{IC}_{50}=7.70 \pm 0.89 \mu \mathrm{M}$ and $5.72 \pm 0.76 \mu \mathrm{M}$ with three times more efficacy than $5-\mathrm{FU}\left(\mathrm{IC}_{50}=25.89 \pm 1.41\right.$ and $\left.16.65 \pm 1.22 \mu \mathrm{M}\right)$, respectively. Moreover, compound 9 (Figure 5) inhibited the MCF-7 cell lines with moderate to good $\mathrm{IC}_{50}=3.54 \pm 0.55 \mu \mathrm{M}$ in comparison to Doxorubicin $\left(\mathrm{IC}_{50}=1.58 \pm 0.2 \mu \mathrm{M}\right)$. It was suggested that presence of $-\mathrm{OH}$ and $-\mathrm{Ph}$ groups at opposite face of pyran ring is the major cause of anti-cancer activity [35].
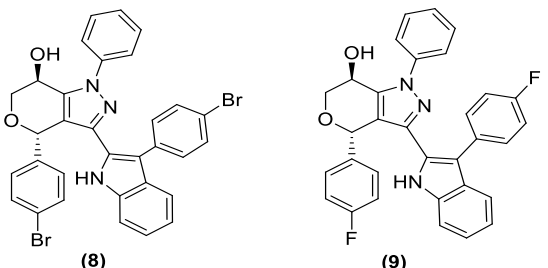

(8)

(9)

Figure 5. Structures of fused pyrazole heterocycles $\mathbf{8}$ and $\mathbf{9 .}$

The prenylation mechanism in cancer causing proteins e.g. Ras (K-Ras/NRas), Ral, Cdc42 and RhoC proteins etc, is catalyzed by FT and GGT1 proteins; thus medicinal chemists has been thrusted towards the development of FT and GGT1 inhibitors for the control of cancer. In order to develop novel inhibitors of prenylation enzymes, Mansha et al. in 2016 reported the synthesis of pyrazole derivatives as structural analogues of GGT1-DU40, GGT1's inhibitor. Among all, compound 10 (Figure 6) effectively inhibit the GGT1 proteins $\left(\mathrm{IC}_{50}=2.4\right.$ $\mu \mathrm{M}$; with fluoro group) as compared to reference drug DU40 $\left(\mathrm{IC}_{50}=3.3 \mu \mathrm{M}\right)$. Through MTT assay it was also observed that MDA-MB-231 cell lines were strongly inhibited by compound $\mathbf{1 0}\left(\mathrm{IC}_{50}=7.6 \pm 1.08 \mu \mathrm{M}\right)$ in comparison to DU40 $\left(\mathrm{IC}_{50}=23.0 \pm 1.22 \mu \mathrm{M}\right)[36]$.

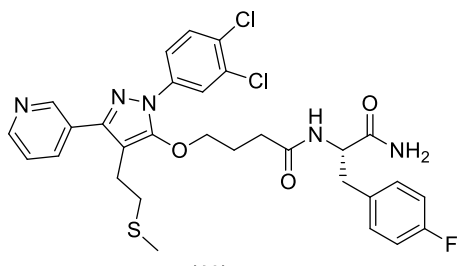

(10)

Figure 6. Structure of potent anticancer pyrazole derivative $\mathbf{1 0 .}$
Synthesis of pyrazolecarboxamide derivatives containing thiol moieties as surface recognition motif was reported by Wen et al. in 2016 in order to develop novel histone deacetylase inhibitors. HDAC (histone deacetylase) inhibitors assay revealed compound 11 (Figure 7) $\left(\mathrm{IC}_{50}=0.08 \pm 0.01 \mu \mathrm{M}\right)$ as highly potent inhibitor against HDACs even three folds of reference drug Vorinostat $\left(\mathrm{IC}_{50} \pm \mathrm{SD}=0.25 \pm 0.09 \mu \mathrm{M}\right)$ and its thiol based analog $\left(\mathrm{IC}_{50} \pm \mathrm{SD}=0.26 \pm 0.06\right.$ $\mu \mathrm{M})$. Moreover, SAR study revealed that different substituent at N-1 position promoted the inhibition activities of compounds in following decreasing order; $-\mathrm{COOH}>-\mathrm{OH}>-\mathrm{R}$ [37]. Esvan et al. in 2016 reported the synthesis of indolopyrazole derivative containing carbazole moiety $\mathbf{1 2}$ (Figure 7) as more selective and potent compound against protein kinases especially Pim family (Pim 1, 2 and 3). Cytotoxicity test revealed it as moderate toxic compound with $\mathrm{IC}_{50}=4.2$ and $4.5 \mu \mathrm{M}$ against HCT116 and leukemia K562 cancer cell lines, respectively. In vitro kinase inhibition assay suggested compound $\mathbf{1 2}$ as good inhibitor of Pim 1and $2\left(\mathrm{IC}_{50}=0.15 \pm 0.02\right.$ and $\left.0.59 \pm 0.04 \mu \mathrm{M}\right)$ but excellent inhibitor of Pim-3 with $\mathrm{IC}_{50}=0.022 \pm 0.009 \mu \mathrm{M}$ but less active towards $\mathrm{PKCa}$ and $\mathrm{PKC}_{\mathrm{Y}}[38]$.
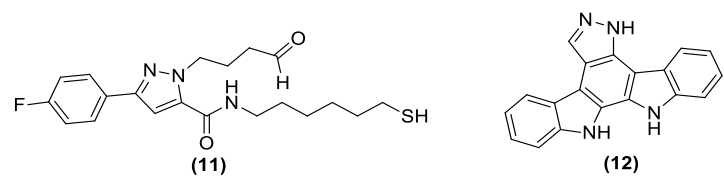

(12)

Figure 7. Pyrazole derivatives $\mathbf{1 1}$ and $\mathbf{1 2}$ with potent anticancer activities.

Carbonic anhydrase IX is an enzyme expressed in carcinomas. In order to hunt potent inhibitors of human carbonic anhydrase (isoforms IX and XII) with higher activity and more selectivity, Ibrahim et al. reported the synthesis of pyrazole derivatives as structural hybrids of benzenesulfonamide and isatin. It was observed that hCA IX (cancer associated) and XII isoforms were strongly inhibited by compound 14 with $K_{i}=2.5 \mathrm{nM}$ and compound 13 with $K_{i}=3.7 \mathrm{nM}$ (Figure 8) [39].

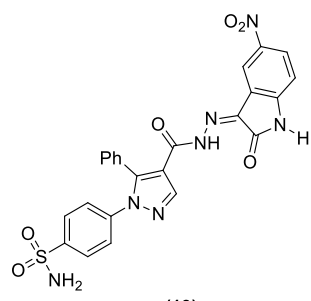

(13)

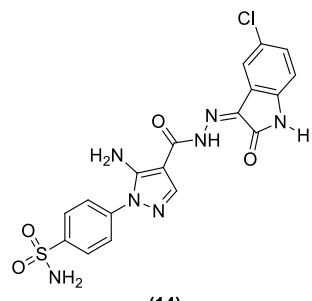

(14)
Figure 8. Structure of hCA XII and hCA IX inhibitors 13 and 14.

Cvijetic et al. in 2015 reported the synthesis of pyrazole derivatives containing the carboxylic acid moieties exhibiting excellent inhibition against hCA IX and XII over hCAI and II with suitable inhibition constant values $\left(\mathrm{k}_{\mathrm{i}}\right)$. Moreover, docking experiments were performed which also explained the selectivity and inhibition activity of these compounds against CA IX and XII. In general, the substitution pattern greatly affected the activity of the synthesized compounds; the derivatives with aryl substituents on the $\mathrm{o}$ - and $\mathrm{m}$ - position of phenyl ring were found to be active whereas, those with bulkier para-substituents were found as inactive. Fields of grid generated molecular-interaction and hydrophobic probes differentiated the active site of CA XII from other three isoforms (I, II and IX) [40].

\section{Antimicrobial activity}

Medicinal chemists have developed a variety of anti-microbial agents but the graph of resistance against many anti-microbial drugs is increasing day-by-day in many pathogens especially in different strains of bacteria [41]. There is urgent need to develop novel anti-biotics with new mode of actions, high selectivity and potency and with less time of therapy [42].

\section{Antibacterial activity}

Pyrazole being the heterocyclic motif have been utilized in order to cope the augmentation of bacterial infection and resistance against anti-biotics [43], for example, Cefoselis is a pyrazole containing anti-bacterial drug which is available in market [44], but still there is a great need to develop novel anti-bacterial drugs. 
Khloya et al. in 2015 reported the synthesis and antibacterial activity of pyrazolylthiazole carboxylic acids and corresponding esters owing to the thiazole and pyrazole nuclei's specific antimicrobial activities. Among all, compound $\mathbf{1 5}$ (Figure 9) was found to be excellent antimicrobial agent as show in Table 3 [45]. In search of efficient antimicrobial agents, chloroquinolinepyrazole derivatives were synthesized by Miniyar et al. in 2015. Compound 16 (Figure 9) was found to be good inhibitor against gram +ve $B$. subtilis and gram -ve E. coli with MIC $=54 \mu \mathrm{g} / \mathrm{ml}$ and $43 \mu \mathrm{g} / \mathrm{ml}$ relative to reference drug Gatifloxacin with $30 \mu \mathrm{g} / \mathrm{ml}$ and $28.5 \mu \mathrm{g} / \mathrm{ml}$, respectively [46].

Table 3. Antibacterial activities of compound $\mathbf{1 5}$ against various strains

\begin{tabular}{|l|c|c|}
\hline Bacterial Strain & MIC $\boldsymbol{\mu g} / \mathbf{m L}$ & Zone of inhibition \\
\hline Staphylococcus aureus & $12.5 \mu \mathrm{g} / \mathrm{mL}$ & $24.6 \mathrm{~mm}$ \\
\hline Bacillus subtilis & $6.25 \mu \mathrm{g} / \mathrm{mL}$ & $29.6 \mathrm{~mm}$ \\
\hline Ciprofloxacin & $6.25 \mu \mathrm{g} / \mathrm{mL}$ & $24 \mathrm{~mm}$ \\
\hline
\end{tabular}<smiles>COc1ccc(-c2nn(-c3ccccc3)cc2-c2nc(-c3ccc(Cl)cc3)c(C(=O)O)s2)cc1</smiles>

(15)

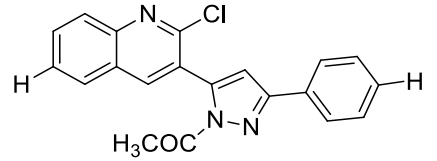

(16)
Figure 9. Structures of pyrazole derivatives $\mathbf{1 5}$ and $\mathbf{1 6}$ exhibiting potent antibacterial activities.

Hussain et al. in 2015 reported the synthesis of potent pyrazole derivatives and inspected their anti-bacterial activities against Staphylococcus aureus (gram +ve) and E. coli (gram -ve). Compound 17 (Figure 10) exhibited excellent antibacterial activity with MIC $=25 \mu \mathrm{g} / \mathrm{ml}$ and $50 \mu \mathrm{g} / \mathrm{ml}$, respectively, in comparison to Ofloxacin with MIC $=10 \mu \mathrm{g} / \mathrm{mL}$ and $12.5 \mu \mathrm{g} / \mathrm{ml}$ against $S$. aureus and E. coli, respectively [47]. Viveka et al. in 2015 reported the synthesis of novel pyrazoline bearing pyrazole derivatives as potent antibacterial agents.

Agar dilution method suggested compound 18 (Figure 10) $(\mathrm{MIC}=0.2 \mathrm{mg} / \mathrm{mL}$ ) as more potent candidate with $34 \mathrm{~mm}$ zone of inhibition than Tetracycline $(\mathrm{MIC}=0.5 \mathrm{mg} / \mathrm{mL})$ and Cefuroxime (MIC $=0.4 \mathrm{mg} / \mathrm{mL})$ against $E$. coli [48].
(17)<smiles>Cc1nn(C(Cl)c2ccncc2)c(C)c1N=Nc1ccc(O)cc1C(=O)O</smiles>

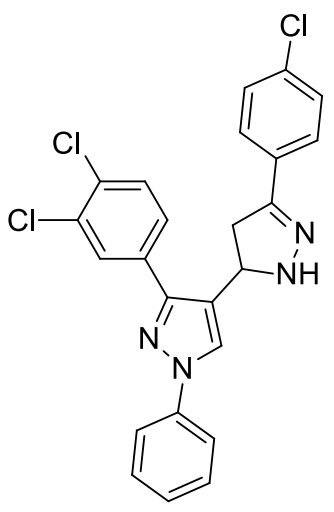

(18)
Figure 10. Structures of antibacterial candidates $\mathbf{1 7}$ and $\mathbf{1 8 .}$

In order to develop novel potential antibacterial agents, $\mathrm{Li}$ et al. in 2015 reported the synthesis of hybrid pyrazole derivative 19 with aminoguanidine moiety. Synthesized derivative was then evaluated for its antibacterial activities by serial dilution method and 96-well plate which revealed that compounds $\mathbf{1 9}$ as potent candidate (Table 4) [49].
Table 4. MIC ( $\mu \mathrm{g} / \mathrm{mL})$ values of compound 19 against various bacterial strains<smiles>N=C(N)N/N=C/c1cn(-c2ccc([N+](=O)[O-])cc2[N+](=O)[O-])nc1-c1cccc(Br)c1</smiles>

(19)

\begin{tabular}{|c|c|c|c|}
\hline Compound & S. aureus & E. coli & MRSA 3167/3506 \\
\hline $\mathbf{1 9}$ & $1 \mu \mathrm{g} / \mathrm{mL}$ & $2 \mu \mathrm{g} / \mathrm{mL}$ & $1 \mu \mathrm{g} / \mathrm{mL}$ \\
\hline Gatifloxacin & $0.25 \mu \mathrm{g} / \mathrm{mL}$ & $2 \mu \mathrm{g} / \mathrm{mL}$ & \\
\hline
\end{tabular}

Nayak et al. in 2015 reported the synthesis of pyrazole derivatives of isonicotinohydrazide as potent antibacterial agents. Microplate alamar blue assay (MABA) was performed to evaluate the antitubercular activities against $M$. tuberculosis H37Rv (MTB) which suggested that compound 21 (Figure 11) (MIC $=1.7 \mu \mathrm{M})$ was found to be most potent inhibitory agent whereas reference drug INH (isoniazid) exhibited MIC $=0.7 \mu \mathrm{M}$. Antibacterial activities were evaluated by well plate method which revealed that almost all compounds were good to moderately active against different bacterial strains. However, compound 20 (Figure 11) (zone of inhibition $=23 \pm 0.2 \mathrm{~mm}$ against Staphylococcus aureus, $24 \pm 0.2 \mathrm{~mm}$ against Escherichia coli and $19 \pm 0.3 \mathrm{~mm}$ against Pseudomonas aeruginosa) at $75 \mu \mathrm{g} / \mathrm{mL}$ concentration was found to be most potent antibacterial agents as compared to reference drug Ciprofloxacin. Similar trend of antibacterial activity was observed when $50 \mu \mathrm{g} / \mathrm{mL}$ concentrations were used [50].

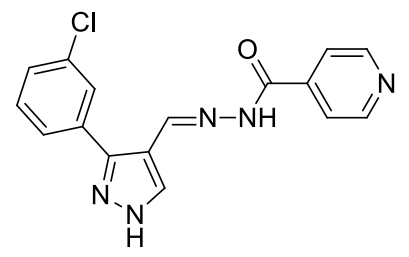

(20)

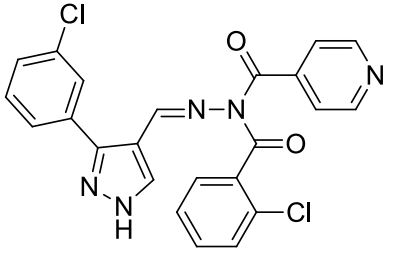

(21)
Figure 11. Pyrazole derivatives 20 and 21 exhibiting antibacterial activities.

Vaarla et al. in 2015 reported the synthesis of coumarin based thiazolylpyrazole derivatives with potent antibacterial activities. It was observed that compound 22 at $100 \mu \mathrm{g} / \mathrm{mL}$ concentration excellently inhibited the $P$. vulgaris, E. coli and K. pneumonia with 20, 22 and $24 \mathrm{~mm}$ zone of inhibition respectively. Compound 22 (Figure 12) was also tested for MIC (minimum inhibitory concentration) and $\mathrm{MBC}$ (minimum bactericidal concentration) and was found to be good inhibitor of B. cereus, K. pneumonia and E. coli with MIC $=72.8 \mu \mathrm{g} / \mathrm{mL}, 79.1 \mu \mathrm{g} / \mathrm{mL}$ and $86.5 \mu \mathrm{g} / \mathrm{mL}$ relative to reference drug Gentamycin with MIC $=10,4$ and $2 \mu \mathrm{g} / \mathrm{mL}$ and with $\mathrm{MBC}=110 \mu \mathrm{g} / \mathrm{mL}, 115$ $\mu \mathrm{g} / \mathrm{mL}$ and $130 \mu \mathrm{g} / \mathrm{mL}$, respectively [31].<smiles>Cc1ccc(-c2nn(-c3nc(-c4cc5cc(Br)cc(Br)c5oc4=O)cs3)cc2C=O)cc1</smiles>

(22)

Figure 12. Antibacterial coumarin based thiazolylpyrazole derivative 22. 
Increasing mortality rate due to drug resistance bacterial strains especially MRSA (methicillin-resistant Staphylococcus aureus) has enormously thrusted the medicinal chemists towards the development of efficient antibacterial drugs. In order to synthesize novel NPL (natural product-like) antibacterial compounds, Yu et al. in 2015 reported the synthesis of pyrazole fused tricyclic diterpenes. Synthesized derivatives were evaluated for antibacterial activities against $S$. aureus strain Newman (Newman) and multidrug- resistant $S$. aureus strains. Among all, compound 23 (Figure 13) $(\mathrm{MIC}=1 \mu \mathrm{g} / \mathrm{mL}$ ) remarkably inhibited $S$. aureus Newman as compared to reference drug Totarol (MIC $=1.56 \mu \mathrm{g} / \mathrm{mL}$ ). Against MDR bacterial strains, compound 24 (Figure 13) $(\mathrm{MIC}=1.56 \mu \mathrm{g} / \mathrm{mL}$ for each) inhibited S. aureus NRS-1, NRS-70, NRS-100, NRS-108 and NRS-271 very efficiently [51].<smiles>CCCc1cc2c(cc1OC)[C@@]1(C)Cc3c[nH]cc3[C@@H](C)[C@]1(C)CC2</smiles>

(23)<smiles>COc1cc2c(cc1Br)C1(C)Cc3c[nH]nc3C(C)C1CC2</smiles>

(24)
Figure 13. Antibacterial pyrazole fused tricyclic diterpenes 23 and 24 .

Nayak et al. in 2016 reported the synthesis of quinoline hybrids of pyrazole derivatives in order to develop more potent compounds with better antibacterial activities. Antibacterial activities were analyzed by well plate method which revealed the zone of inhibition of compound 25 (Figure 14) $(20 \pm 0.3,24 \pm 0.2$ and $18 \pm 0.1 \mathrm{~mm}$ ) against Staphylococcus aureus, Escherichia coli and Pseudomonas aeruginosa respectively which demonstrated its potential utility as anti-bacterial agent [52].<smiles>Cc1cc(N/N=C/c2c[nH]nc2-c2cccc(Cl)c2)c2cccc(C(F)(F)F)c2n1</smiles>

(25)

Figure 14. Structure of antibacterial quinoline hybrid of pyrazole derivative 25.

\section{Antifungal activity}

This is usually difficult to treat fungal infection, therefore, there is need to develop more potent and highly selective anti-fungal agents such as Pyraclostrobin and Penthiopyrad [53 - 54]. In order to innovate the novel compounds with more pharmacological activities, Hussain et al. in 2015 reported the synthesis of novel diazenylpyrazole derivatives. Dish fusion method was utilized to evaluate their in vitro anti-fungal activities against fungal strain $A$. niger. It was observed that among all derivatives compound 26 (Figure 15) showed better antifungal activity ( $\mathrm{MIC}=25 \mu \mathrm{g} / \mathrm{L}$ ) close to reference drug Ketoconazole ( $\mathrm{MIC}=12.5 \mu \mathrm{g} \mathrm{m} / \mathrm{L}$ ) [47]. Li et al. in 2015 reported the synthesis of hybrid pyrazole derivatives with furan-2-carbohydrazide or aminoguanidine moieties as potent pharmaceutical agents. It was observed that among all derivatives compound 27 (Figure 15) showed best antifungal activity with MIC $=1 \mu \mathrm{g} / \mathrm{mL}$ against $C$. albicans relative to reference drug Fluconazole (MIC $=1$ $\mu \mathrm{g} / \mathrm{mL})[49]$.

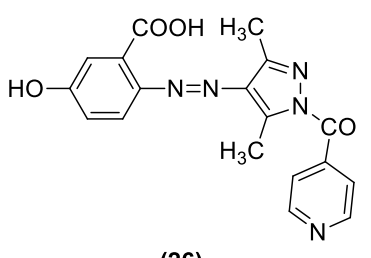

(26)

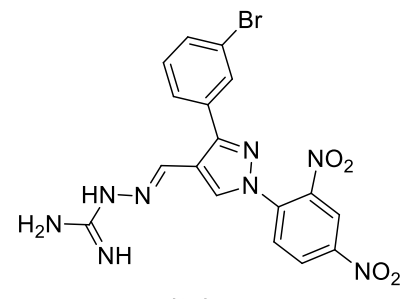

(27)
Figure 15. Structures of anti-fungal pyrazole derivatives 26 and 27.
Sharma and co-workers in 2015 reported the synthesis of pyrazolylthiazole carboxylic acid 28 (Figure 16) and screened its anti-fungal activity against two fungal strains Saccharomyces cerevisiae and Candida albicans. It was observed that compound 28 (Figure 15) with $27.6 \mathrm{~mm}$ (MIC $6.25 \mu \mathrm{g} / \mathrm{mL}$ ) zone of inhibition showed better results against both strains in comparison to reference drug Amphotericin B with zone of inhibition $19.3 \mathrm{~mm}(\mathrm{MIC}=6.25 \mu \mathrm{g} / \mathrm{mL})$ and $16.6 \mathrm{~mm}(\mathrm{MIC}=6.25 \mu \mathrm{g} / \mathrm{mL})$, respectively [45]. In search of efficient antifungal agents, chloroquinolinepyrazole derivatives were synthesized by Miniyar and coworkers in 2015 . It was observed that antifungal activity was greatly dependant on substitution pattern and increased by introducing electron donating groups at para position as compared to electron withdrawing groups. Compound 29 (Fig. 16) (p-amino derivative) was found to be more promising antifungal agent with $\mathrm{MIC}=46 \mu \mathrm{g} / \mathrm{ml}$ against $P$. notatum and $\mathrm{MIC}=48 \mu \mathrm{g} / \mathrm{ml}$ against A. fumigatus relative to reference drug with $\mathrm{MIC}=30.5 \& 32.5 \mu \mathrm{g} / \mathrm{ml}$, respectively [46].

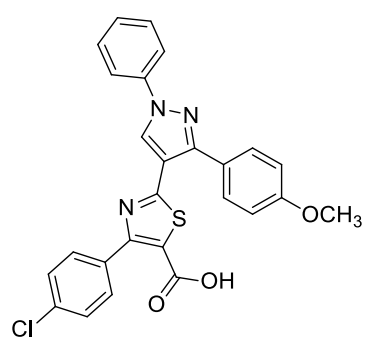

(28)
(29)

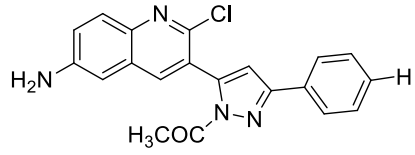

Figure 16. Structures of pyrazole derivatives 28 and 29 with antifungal activities.

\section{Antiviral}

Pyrazole derivative 30 (Figure 17) was synthesized by Jia et al. in 2016 and was reported as potent inhibitor against secretion of HBsAG (surface antigen of $\mathrm{HBV})\left(\mathrm{IC}_{50}=24.33\right)$ and $\mathrm{HBeAG}$ (envelop antigen of $\left.\mathrm{HBV}\right)\left(\mathrm{IC}_{50}=2.22\right)$ [55]. In order to hunt potent anti-BVDV (bovine viral diarrhea virus) agents as well as molecules with efficient DNA binding/cleaving activities, Han et al. in 2015 reported the synthesis of alternate novel pyrazole derivatives bearing tetramic acid subunits. Electronic absorption study of the synthetic derivatives suggested that metal complexes (Cu (II)) of compound $\mathbf{3 1}$ having no $\mathrm{N}$-substituent on pyrazole ring were found to be good DNA binder. Ligand dependant DNA cleavage studies were performed which revealed that at $\mathrm{pH} 7$ complex $3 \mathrm{~b}-\mathrm{Cu}^{2+}$ $\left(0.20 \mathrm{mmol} / \mathrm{L}\right.$ conc) with $24 \mathrm{~h}$ incubation at $37{ }^{\circ} \mathrm{C}$ showed the remarkable supercoiled DNA (pUC 19 plasmid DNA) cleavage to nicked DNA via hydrolytic pathway. Anti-BVDV activities of selected compounds were inspected on MDBK cells via MTT assay. It was observed that compound 32 (Figure 17) $\left(\mathrm{EC}_{50}=0.12 \mu \mathrm{mol} / \mathrm{L}\right)$ performed well as anti-viral agent as compared to reference drug Ribavirin $\left(\mathrm{EC}_{50}=1.3 \mu \mathrm{mol} / \mathrm{L}\right)[56]$.

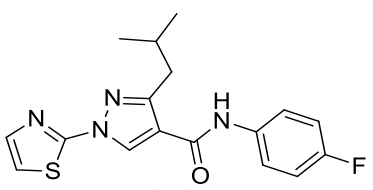

(30)

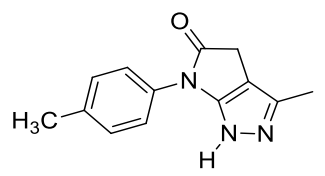

(31)

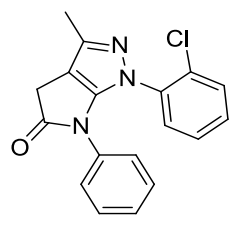

(32)

Figure 17. Structures of selected compounds $\mathbf{3 1}$ and $\mathbf{3 2}$ against BVDV.

\section{Anti-inflammatory and analgesic effects}

Long term use of non-steroidal anti-inflammatory drugs becomes the cause of gastric ulceration and bleeding [57]. Synthesis of NSAIDs (non-steroidal antiinflammatory drugs) with less damaging upshots has seizured the heed of pharmacists. 
Hussain et al. in 2015 reported the synthesis of novel diazenylpyrazole derivatives and scrutinized their anti-inflammatory activity by carrageenaninduced rat paw edema method which disclosed compound $\mathbf{3 3}$ (Figure 18) as best anti-inflammatory agents (with $80.29 \%$ anti-inflammatory activity very close to reference drug ibuprofen $(80.38 \%)$. It was observed that compounds having less gastro-intestinal ulceration activity also showed less lipid peroxidation in the range of $3.25 \pm 0.05$, on the other hand reference drugs flurbiprofen $(7.51 \pm 0.68)$ and ibuprofen $(7.79 \pm 0.13)$ showed higher index of lipid peroxidation, additionally did not exhibited histopathology of liver. As well as compound $\mathbf{3 3}$ was also manifested as moderate pain killer with less ulcerogenic effects with activities running between $0.333 \pm 0.10$ to $1.000 \pm 0.31$ while $2.000 \pm 0.13$ and $1.666 \pm 0.24$ were the ulcerogenic activities of Flurbiprofen and Ibuprofen [47].<smiles>Cc1nn(C(N)=S)c(C)c1N=Nc1ccc(F)cc1Cl</smiles>

(33)

Figure 18. Structure of pyrazole based anti-inflammatory compound $\mathbf{3 3}$.

Pyrazolylthiazole carboxylic ester $\mathbf{3 4}$ was prepared by Khloya et al in 2015 . Carrageenan-induced rat paw edema method revealed that compound 34 (Figure 19)(93.06\%) exhibited excellent anti-inflammatory activity after $3 \mathrm{~h}$ of carrageenan injection in comparison to reference drug Indomethacin $(91.32 \%$ AI) [45]. Viveka et al. in 2015 reported the synthesis of novel pyrazoline bearing pyrazole derivatives as potent anti-inflammatory agents. Carrageenan-induced rat paw edema method suggested compound $\mathbf{3 5}$ containing $\mathrm{N}$-acyl moiety with $75.56 \%$ inhibition within 120 min of reaction time, as potent anti-inflammatory compound (Figure 19). Analgesic activities were tested by tail flick latency test and compound 35 (Figure 19) with $7.7 \pm 0.1$ tail flick latency in secs was found to be exhibited best analgesic effects very close to Pentazocin (with $7.7 \pm 0.1$ tail flick latency in secs) [48].<smiles>CCOC(=O)c1sc(-c2cn(-c3ccccc3)nc2-c2ccc(Cl)cc2)nc1-c1ccc(Cl)cc1</smiles>

(34)

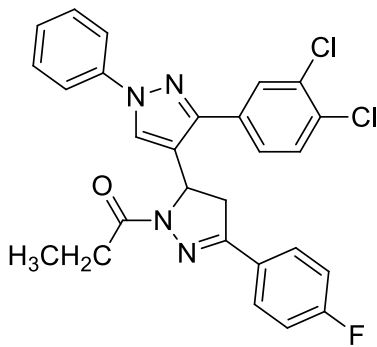

(35)
Figure 19. Structures of anti-inflammatory and analgesic agents $\mathbf{3 4}$ and $\mathbf{3 5}$.

In order to synthesize safe NSAIDs, Abdellatif et al. in 2015 reported the synthesis of pyrazoline and pyrazole derivatives as celecoxib analogs. The synthesized pyrazole and pyrazoline were further evaluated for biological activities as anti-inflammatory agent and cyclooxygenase 1 and 2 (COX-1 and COX-2) inhibitors. In vitro cyclooxygenase inhibition assay which was carried out to evaluate inhibition activities of targeted compounds which revealed that synthesized derivatives were excellent inhibitors of COX-2 $\left(\mathrm{IC}_{50}=0.97-10.8\right.$ $\mu \mathrm{M})$ but poor inhibitors of $\mathrm{COX}-1\left(\mathrm{IC}_{50}=5.6-24.1 \mu \mathrm{M}\right)$. Moreover, compounds 36 (Figure 20) $\left(\mathrm{ED}_{50}=190.5 \mu \mathrm{mol} / \mathrm{Kg}\right)$ with $41.3 \%$ inhibition was found to be most potent $\mathrm{AI}$ candidate more than the reference drugs Aspirin $\left(\mathrm{ED}_{50}=710\right.$ $\mu \mathrm{mol} / \mathrm{Kg}$ po $)$ and Ibuprofen $\left(\mathrm{ED}_{50}=327 \mu \mathrm{mol} / \mathrm{Kg}\right.$ po $)$ but less effective than Celecoxib $\left(\mathrm{ED}_{50}=30.9 \mu \mathrm{mol} / \mathrm{Kg}\right.$ po $)$ [58]. In order to develop novel potential AI's (anti-inflammatory) agents, Li et al. in 2015 reported the synthesis of hybrid pyrazole derivatives with furan-2-carbohydrazide or aminoguanidine moieties. Ear edema method (induced by xylene) was used for the evaluation of antiinflammatory activities of synthesized derivatives. Excellent inhibition rate (93.59\%) was shown by compound 37 (Figure 20) greater than the reference drugs Indometacin (45.23\%) and Ibuprofen (29.56\%) [49].

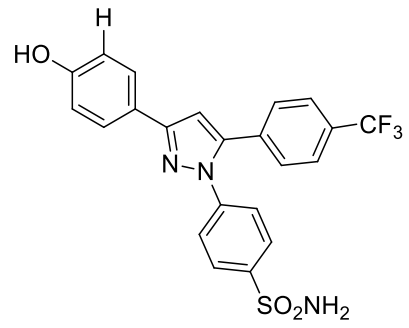

(36)<smiles>N=C(N)N/N=C/c1cn(-c2ccccc2)nc1-c1cccc(Cl)c1</smiles>

(37)
Figure 20. Structures of compound $\mathbf{3 6}$ and $\mathbf{3 7}$ potent anti-inflammatory activity.

Based upon the concept of bioisosterism, EI-Feky et al. in 2015 reported the synthesis of novel pyrazole derivative $\mathbf{3 8}$ bearing quinolines via Pfitzinger reaction II. Their COX (cyclooxegenase) inhibition activity was checked by using COX-1/COX-2 assay kit which revealed compound 38 (Figure 21) having electronegative atom chlorine as potent inhibitor of COX-2 with $\mathrm{IC}_{50}=0.26 \mu \mathrm{M}$ and $\mathrm{SI}>192.33$ in comparison to Celecoxib $\left(\mathrm{IC}_{50}=0.28 \mu \mathrm{M}\right.$ with $\left.\mathrm{SI}>178.57\right)$. In case of COX-1 all derivatives as well as Celecoxib showed $\mathrm{IC}_{50}>50 \mu \mathrm{M}$. Moreover, compound 38 with $0.75 \pm 0.03 \mathrm{~mm}$ thickness of paw skin was found to be good anti-inflammatory agent whereas the reference drug Celecoxib showed $0.7 \pm 0.02 \mathrm{~mm}$ thickness of paw skin [59]. Thore et al. in 2016 reported the synthesis of methylthiopyrazole derivatives containing carboxylate moieties. Carrageenan induced paw edema method revealed the potent anti-inflammatory activity of 39 (Figure 21) with $44.48 \%$ inhibition while diclofenac exhibited $46.20 \%$ of inhibition after $2 \mathrm{~h}$ of treatment. Compound $\mathbf{3 9}$ was also tested for ulcerogenic effect. It was found that tested compound showed less ulcer index with $1.12 \pm 0.62$ ulcer indexes in comparison to standard drug with $3.10 \pm 0.75$ ulcer indexes [60].<smiles>CCOC(=O)c1cnn(C(=O)c2cc(-c3ccc(Cl)cc3)nc3ccc(OC)cc23)c1N</smiles>

(38)

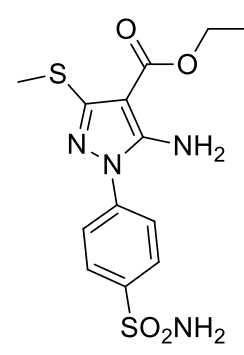

(39)
Figure 21. Structures of pyrazole based anti-inflammatory compounds $\mathbf{3 8}$ and 39.

\section{Insecticidal activity}

Now-a-days among the most serious threats in crop health and protection are the agrochemical pests and insects [61]. Pyrazole being a heterocyclic moiety have played a major role in agro chemistry. Cyantraniliprole, Chlorantraniliprole and Pyriprole are one of those pyrazolederivates that are available in market as commercial pesticides [62]. Involvement of EcR-USP (ecdysone receptorultraspiracle protein) heterodimeric receptors in molting has coaxed the pharmacists towards the synthesis of potent EcR-USP based ligands to assist and enhance the ecdysis in environmental friendly insects. In this context, Deng et al. in 2016 reported the synthesis potent ligands of heterodimeric EcR-USP as structural analogues of BYIO6830 and VS008 having potent insecticidal activity against few lepidopteran pests too. The synthesized pyrazole amide derivatives were then evaluated for their insecticidal activities against Helicoverpaarmigera, Mythimnaseparata and Pyraustanubilalis. It was observed that among all, compound 40 with 3-methoxy group exhibited potent activities in comparison to positive control of Tebufenozide. Compound $\mathbf{4 0}$ (Figure 22) was found to be most potent compound with $100 \%$ mortality rate against all insects. Moreover, molecular docking studies were performed to investigate the target site on EcR subunits, binding free energy of ligands and to investigate the ligand's binding mechanism at active site of EcR subunits and it was observed that mode of action of compound $\mathbf{4 0}$ was similar to Tebufenozide as EcR-USP heterodimeric binder [63]. 


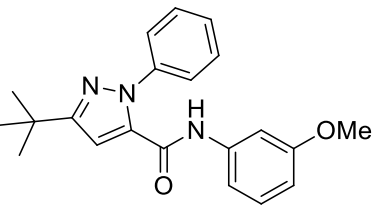

(40)

Figure 22. Structure of heterodimeric EcR-USP pyrazole derivative 40.

In order to get best insecticidal compounds, chiral 1-(3-chloropyridine-2-yl)3-) trifluoromethyl)-1 $\mathrm{H}$-pyrazole-4-carboxamide derivatives were synthesized by Liu et al. in 2016 via successful incorporation of flexible alkyl chain between benzene ring and trifluoromethylpyridine. The synthesized fluorinated pyrazolecarboxamide derivatives were further evaluated for their inhibition activities $(100 \%$ at $40 \mathrm{~m})$ against the tomato root-knot nematode disease caused by Meloidogyne incognita. The docking study revealed that among other derivatives compound 41 (Figure 23) was found to be more potent and exhibited best binding mode with AchE (acetyl cholinesterase) via two $H$ bonds [64].

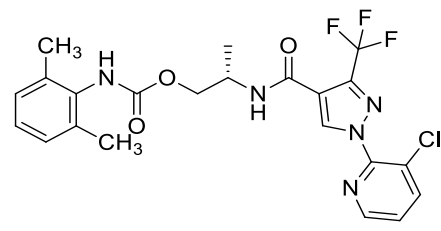

(41)

Figure 23. Structure of pyrazole derivative $\mathbf{4 1}$ exhibiting insecticidal activity.

\section{Immunosuppressant activity}

Pyrazole derivatives containing $O$-benzyl oxime moiety were synthesized as more potent immunosuppressive agents with less toxicity by Lv et al. in 2016 . Structural modifications suggested that immunosuppressive activity increased by varying para substituent on ring $\mathrm{A}$ and ortho substituent on ring $\mathrm{B}$ with electron withdrawing groups in following order respectively; $\mathrm{F}>\mathrm{Cl}>\mathrm{OMe}>\mathrm{H}>\mathrm{Me}$ (for ring $\mathrm{A}$ ) and $\mathrm{F}>\mathrm{Cl}>\mathrm{H}$ (for ring $\mathrm{B}$ ). P13KV enzymatic inhibitory activity of selected compounds was also checked which also suggested compound $\mathbf{4 2}\left(\mathrm{IC}_{50}\right.$ $=7.2 \mu \mathrm{M})$ was the best potent candidate as compared to reference compound LY294002 $\left(\mathrm{IC}_{50}=7.2 \mu \mathrm{M}\right)$. Cytotoxicity and inhibitory activities were evaluated of pyrazole derivatives on lymph node cells and by inhibiting proliferation of $\mathrm{T}$. cells stimulated by ConA (concanavalin A) respectively, which suggested that compound 42 (Figure 24) was most potent with less toxicity $\left(\mathrm{CC}_{50} \pm \mathrm{SD}=259.12\right.$ $\pm 22.72 \mu \mathrm{M})$ and excellent inhibitory activity $\left(\mathrm{IC}_{50} \pm \mathrm{SD}=1.18 \pm 0.26 \mu \mathrm{M}\right)$. Moreover, compound $\mathbf{4 2}$ was also found to be most potent compound which showed strong inhibition against the expression of IL-6 mRNA [65].

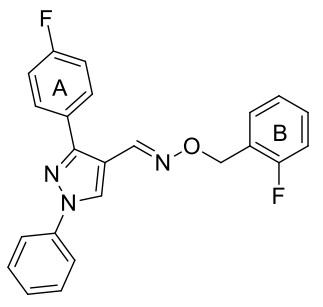

(42)

Figure 24. Immunosuppressive agent 42 based on pyrazole ring.

\section{Anti-enzymatic}

\section{Anti-SIRT1 and SIRT2}

While working on the development of new unparalleled compounds with inhibitory activity against sertuin enzymes class III SIRT1 and SIRT2, Therrien et al. in 2015 reported the synthesis of bicyclic pyrazole derivatives. In general, the synthesized hydrate bicyclic pyrazole derivatives showed moderate to low inhibitory activities. Among all derivatives, compound $\mathbf{4 3}$ (Figure 25) was found to be most active, however, with moderate inhibitory activity against SIRT1 with $\mathrm{IC}_{50}=1 \mu \mathrm{M}$ and with low inhibitory activity against SIRT2 $\left(\mathrm{IC}_{50}=43 \%\right)[66]$.

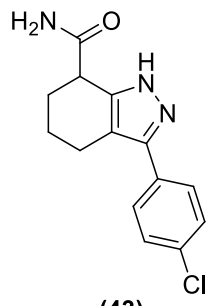

(43)

Figure 25. Structure of pyrazole based anti- SIRT1 and SIRT2 compound $\mathbf{4 3}$

\section{Anti-FAAH}

The degradation of neurotransmitters by FAAH (fatty acid amide hydrolase) resulting in neuropathic pain has posed a challenge for scientists. In order to come across potent compounds with desired inhibitory activities, Tabrizi and coworkers in 2015 synthesized a series of pyrazole derivatives containing phenyl cyclohexyl carbamate moiety. Among selected active compounds, compound $\mathbf{4 4}$ (Figure 26) was found to be most vigorous inhibitor against FAAH with $\mathrm{IC}_{50}=$ $11 \mathrm{nM}$ even greater than the reference drug CAY10499 $\left(\mathrm{IC}_{50}=14 \mathrm{nM}\right)$ [67].

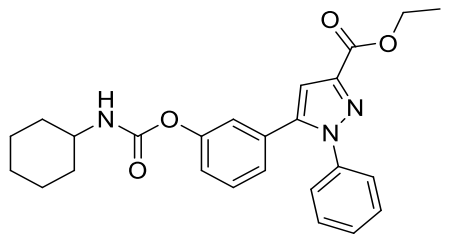

(44)

Figure 26. Structure of selected compound $\mathbf{4 4}$ against FAAH.

\section{Anti-nitric oxide synthase (NOSs)}

Nieto et al. in 2015 reported the synthesis of trifluoromethylpyrazole derivatives based upon hemicurcuminoids. Synthesized compounds were then evaluated for their inhibition potential against NOSs (nNOS, iNOS and eNOS). Among all, compound 45 (Figure 27) strongly inhibited the eNOS with almost $56.8 \%$ inhibition. While compound $\mathbf{4 6}$ efficiently inhibited the nNOS and iNOS with almost $52.9 \%$ and $68.8 \%$ inhibition (Figure 27) [68].<smiles>Oc1ccc(/C=C/c2cc(C(F)(F)F)n[nH]2)c(F)c1</smiles>

(45)<smiles>Oc1c(F)ccc(/C=C/c2cc(C(F)(F)F)n[nH]2)c1F</smiles>

(46)
Figure 27. Pyrazole based anti-nitric oxide synthase $\mathbf{4 5}$ and $\mathbf{4 6}$.

\section{Liver X Receptor (LXR) partial agonist}

For the synthesis of liver X receptors especially LXR $\beta$ agonist's Kick and coworkers in 2015 reported the synthesis of imidazole and pyrazole derivatives. Pyrazole and imidazole derivatives then evaluated for biological activities especially for LXR $\alpha$ agonism and LXR $\beta$ selectivity. Best results were obtained in case of compound 47 (Figure 28) which was found to be LXR partial agonist showing $72 \%$ LXR $\beta$ selectivity [69].

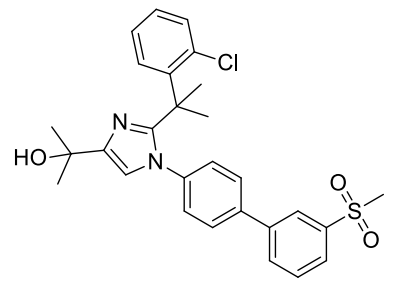

(47)

Figure 28. Structure of LXR partial agonist 47. 


\section{$\mathrm{CB}_{2}$ receptor ligands}

$\mathrm{CB}_{2}$ receptors being the part of neurons and brain cells have been identified responsible to control the movement, sensory perception, memory and emotions etc. Thus, it becomes meaningful for medicinal chemists to target $\mathrm{CB}_{2}$ receptors for the treatment of neurological disorders. In this regard, Deiana et al. in 2016 reported the synthesis of tricyclic pyrazole derivatives with variety of carboxamides as antagonist agonist of $\mathrm{CB}_{2}$ receptor. According to Radio ligand assay compound $\mathbf{4 8}$ was found to be more potent with better affinities towards $\mathrm{CB}_{2}$ receptors with $\mathrm{K}_{\mathrm{i}}$ values $(6 \pm 1 \mathrm{nM})$. Whereas, reference compounds $A$ and B showed $0.037 \pm 0.003 \mathrm{nM}$ and $1079 \pm 44 \mathrm{nM} \mathrm{K}$ values respectively. Moreover, Compound 48 (Figure 29) was found to possess remarkable selectivity towards $\mathrm{CB}_{2}$ receptors with $\mathrm{K}_{\mathrm{i}} \mathrm{CB}_{2}$ selectivity $>6944$. Functional activities at $\mathrm{CB}_{2}$ receptors were also evaluated of synthesized compounds via $\mathrm{GTP}_{\gamma} \mathrm{S}$ assay and found to be antagonist agonists. Compound $\mathbf{4 8}$ was found to be most potent candidate with $\mathrm{IC}_{50}=80.4 \pm 17.0 \mathrm{nM}$ [70].

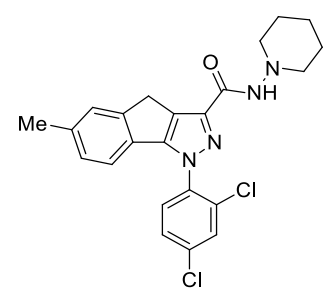

(A)

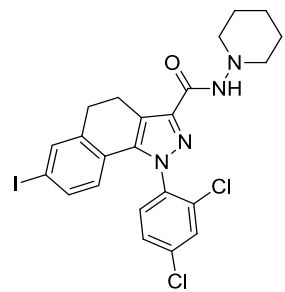

(B)

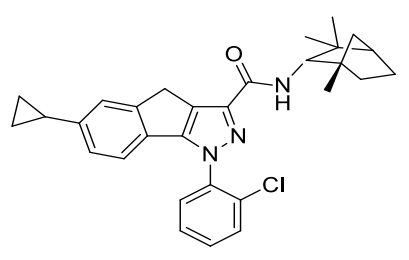

(48)

Figure 29. Structure of $\mathrm{CB}_{2}$ receptor ligand 48 .

\section{Glucagon receptor antagonists}

Day-by-day increasing rate of insulin resistance and hyperglycemia due to type 2 diabetes mellitus (T2DM) has mediated the scientists towards the synthesis of more efficient and safer drugs. In this regard, Shu et al. in 2016 reported the synthesis of novel pyrazole derivative as antagonists of glucagon receptors based on conformational restrain and bioisoteric strategies. In vitro glucagon receptors antagonism activity and functional cAMP activities of the synthesized compounds revealed compound 49 (Figure 30 ) to be potent GCGR binder $\left(\mathrm{IC}_{50}\right.$ $=3.6 \pm 0.5 \mu \mathrm{M})$ with good cAMP response $(1.2 \pm 0.3 \mu \mathrm{M})[71]$.

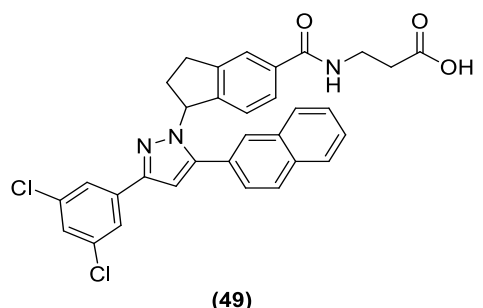

(49)

Figure 30. Pyrazole based glucagon receptor agonist 49.

\section{CONCLUSIONS}

From the above literature survey, we could conclude that pyrazole has immensely turned the interest of medicinal chemists towards the synthesis of its biologically active derivatives. These pyrazole derivatives have fascinating display of pharmacological profile. This comprehensive review will provide the bioactivities of medicinally important pyrazole derivatives against divergent diseases. Also, with the alarming situation of health problems, the quest to develop more potent and highly selective pyrazole derivatives should be continued.

\section{ACKNOWLEDGEMENTS}

The authors are really grateful to GC University, Faisalabad for provision of platform and other facilities to carry out this work.

\section{REFERENCES}

1. K. Du, Y. J. Mei, X. T. Cao, P. F. Zhang and H. Zheng, Int. J. Chem. Eng. Appl. 4, 238, (2013).

2. X. Zhang, J. Kang, P. Niu, J. Wu, W. Yu and J. Chang, J. Org. Chem. 79, 10170, (2014).

3. S. Dadiboyena and A. Nefzi, Eur. J. Med. Chem. 46, 5258, (2011).

4. R. Harigae, K. Moriyama and H. Togo, J. Org. Chem. 79, 2049, (2014)

5. D. Ashok, M. G. Devulapally, S. Gundu, V. K. Aamate, S. Chintalapally, J. Heterocyclic. Chem. 52(8), 609, (2016).

6. B. P. Bandgar, S. S. Gawande, R. G. Bodade, N. M. Gawande, C. N. Khobragade, Bioorg. Med. Chem. 17, 8168, (2009).

7. A. A. Bekhit and T. A. Aziem, Bioorg. Med. Chem. 12, 1935, (2004).

8. S. Y. Hassan, Molecules, 18, 2683, (2013).

9. S. Mert, R. Kasmogullan, T. Ica, F. Colak, A. Altun and S. Ok, Eur. J. Med. Chem. 78, 86, (2014).

10. D. Pal, S. Saha and S. Singh, Int. J. Pharm. Pharm. Sci. 4, 98, (2012)

11. A. W. Brown, Adv. Heterocycl. Chem. 126, 55, (2018).

12. Y. A. Siu, M. H. Hao, V. Dixit, W. G. Lai, Drug. Metab. Pharmacok. (2018).

13. K. R. A. Abdellatif, W. A. A. Fadaly, Y. A. M. M. Elshaier, W. A. M. Ali and G. M. Kamel, Bioorg. Chem. 77, 568, (2018).

14. G. B. Onoa and V. Moreno, Int. J. Pharm. 245, 55, (2002).

15. A. Porcu, M. Melis, R. Turecek, C. Ullrich, I. Mocci, B. Bettler, G. L. Gessa and M. P. Castelli, Neuropharmacology, 133, 107, (2018).

16. C. Shi, C. Ma, H. Ma, X. Zhou, J. Cao and Y. Fan, Tetrahedron, 72, 4055, (2016).

17. A. Hughes, R. G. Hendrikson and B. C. Chen, M. Valento, Am. J. Emerg. Med. 36, 1527.e3, (2018).

18. Q. Huang, G. Tran, D. G. Pardo, T. Tsuchiya, S. Hillebrand, J. P. Vors and J. Cossy, Tetrahedron, 71, 7250, (2015).

19. K. B. Millins, J. M. Thomason, K. V. Lunsford, L. M. Pinchuk, V. C. Langston, R. W. Wills, R. M. Mclaughlin and A. J. Mackin, Vet. Anaesth. Analg. 39, 206, (2012).

20. M. M. G. El-Din, M. I. El-Din, M. S. A. Maksoud, K. H. Yoo, D. Baek, J. Choi, H. Lee and C. H. Oh, J. Enzym. Inhib. Med. Ch. 31, 111, (2016).

21. R. Alam, D. Wahi, R. Singh, D. Sinha, V. Tandon, A. Grover and Rahisuddin, Bioorg. Med. Chem. 69, 77, (2016).

22. A. Pearce, M. Haas, R. Viney, S. A. Pearson, P. Haywood, C. Brown and R. Ward, PLOS ONE, 1, (2017).

23. A. Sahu, K. Prabhash, V. Noronha, A. Joshi and S. Desai, South Asian J. Cancer, 2, 91, (2017).

24. A. T. Shaw, D. W. Kim, K. Nakagawa, T. Seto, L. Crino, M. J. Ahn, T. D. Pas, B. Besse, B. J. Solomon, F. Blackhall, Y. L. Wu, M. Thomas, K. J. O. Byrne, D. Sibilot, D. R. Camidge, T. Mok, V. Hirsh, G. J. Riely, S. Lyer, V. Tassell, A. Polli, K. D. Wilner and P. A. Janne, N. Engl. J. Med. 368, 20385, (2013).

25. M. M. G. El-Din, M. I. El-Gamal, M. S. A. Maksoud, K. H. Yoo and C. H Oh, Eur. J. Med. Chem. 119, 122, (2016).

26. R. Dummer, P. A. Ascierto, H. J. Gogas, A. Arance, M. Mandala, G. Liszkay, C. Garbe, D. Schadendorf, L. Krajsova, R. Gutzmer, V. C. Sileni, C. Dutriaux, J. W. Groot, N. Yamazaki, C. Loquai, L. A. M. D. Parseval, M D. Pickard, V. Sandor, C. Robert and K. T. Flaherty, Lancet Oncol. 1 , (2018).

27. A. Balbi, M. Anzaldi, C. Maccio, C. Aiello, M. Mazzei, Mauro Mazzei, R. Gangemi, P. Castagnola, M. Miele, C. Rosano, M. Viale, Eur. J. Med. Chem 46, 5293, (2011).

28. X. H. Lv, Z. L. Ren, B. G. Zhou, Q. S. Li, M. J. Chu, D. H. Liu, K. Mo, L. S. Zhand, X. K. Yao and H. Q. Cao, Bioorg. Med. Chem. 24, 4652, (2016).

29. V. G. Reddy, T. S. Reddy, V. L. Nayak, B. Prasad, A. P. Reddy, A. Ravikumar, S. Taj and A. Kamal, Eur. J. Med. Chem. 122, 164, (2016).

30. S. F. Wang, Y. Yin, Y. L. Zhang, S. W. Mi,M. Y. Zhao, P. C. Lv, B. Z. Wang and H. L. Zhu, Eur. J. Med. Chem. 93, 291, (2015).

31. K. Vaarla, R. K. Kesharwani, K. Santosh, R. R. Vedula, S. Kotamraju, M. K. Toopurani, Bioorg. Med. Chem. Lett. 25, 5797, (2015). 
32. A. Kamal, A. B. Shaik, N. Jain, C. Kishor, A. Nagabhushhana, B. Supriya, G. B. Kumar, S. S. Chourasiya, Y. Suresh, R. K. Mishra and A. Addlagatta, Eur. J. Med. Chem. 92, 501, (2015).

33. H. Zhang, P. Zhu, J. Liu, Y. Lin, H. Yao, J. Jiang, W. Ye, X. Wu and J. Xu, Bioorg. Med. Chem. Lett. 25, 728, (2015).

34. G. Bertuzzi, E. Locatelli, D. Colecchia, P. Calandro, B.F. Bonini, J. Z. Chandanshive, A. Mazzanti, P. Zani, M. Chiariello and M. C. Franchini, Eur. J. Med. Chem. 117, 1, (2016).

35. F. Q. Wang, H. Yang, B. He, Y. K. Jia, S. Y. Meng, C. Zhang, H. M. Liu and F. W. Liu, Tetrahedron Lett. 72, 5769, (2016).

36. M. Mansha, U. U. Kumari, Z. Cournia and N. Ullah, Eur. J. Med. Chem. 124, 666, (2016).

37. J. Wen, Q. Niu, J. Liu, Y. Bao, J. Yang, S. Luan, Y. Fan, D. Liu and L. Zhao, Bioorg. Med. Chem. Lett., 26, 375, (2016).

38. Y. J. Esvan, F. Giraud, E. Pereira, E. Pereira, V. Schuaud, L. Nauton, V. Thery, L. G. Dezhenkova, D. N. Kaluzhny, V. N. Mazov, A. A. Shtil, F. Anizon and P. Moreau, Bioorg. Med. Chem. 24, 3116, (2016).

39. H. S. Ibrahim, S. M. A.Seri, M. Tanc, M. M. Elaasser, H. A. A. Aziz and C. T. Supuran, Eur. J. Med. Chem. 103, 583, (2015).

40. I. N. Cvijetic, M. Tanc, I. O. Juranic, T. Z. Verbic, C. T. Supuran and B. J. Drakulic, Bioorg. Med. Chem. 23, 4649, (2015).

41. M. Bhat, G. K. Nagaraja, D. P. Divyaraj, H. N., S. R. Pai, S. Biswas, P. S. K., RSC Adv., 1, (2016).

42. V. Dhanapal, J. Ramalingam and A. N. Raman, J. Heterocyclic Chem., 9999 (2016).

43. M. Bhat, G. K. Nagaraja, R. Kayarmar, P. S. K. and M. S. R., RSC Adv., 6, 59375, (2016).

44. P. Zalewski, R. Skibinski, A. Talaczynska, m. Paczkowska, P. Garbacki and J. C. Piontek, J. Pharm. Biomed. Anal., 114, 222, (2015).

45. P. Khloya, S. Kumar, P. Kaushik, P. Surain, D. Kaushik and P. K. Sharma, Bioorg. Med. Chem. Lett. 25, 1177, (2015).

46. P. B. Miniyar, M. A. Barmade and A. A. Mahajan, J. Saudi Chem. Soc. 19, 655, (2015).

47. S. Hussain and D. Kaushik, J. Saudi Chem. Soc. 19, 274, (2015).

48. S. Viveka, Dinesha, P. Shama, G. K. Nagaraja, S. Ballav and S. Kerkar, Eur. J. Med. Chem. 101, 442, (2015).

49. Y. R. Li, C. Li, J. C. Liu, M. Guo, T. Y. Zhang, L. P. Sun, C. J. Zheng and H. R. Piao, Bioorg. Med. Chem. Lett. 25, 5052, (2015).

50. N. Nayak, J. Ramprasad and U. Dalimba, Bioorg. Med. Chem. Lett. 25, 5540, (2015).

51. L. G. Yu, T. F. Ni, W. Gao, Y. He, Y. Y. Wnag, H. W. Cui, C. G. Yang and W. W. Qiu, Eur. J. Med. Chem. 90, 10, (2015).

52. N. Nayak, J. Ramprasad and U. Dalimba, J. Fluorine Chem. 183, 59, (2016).
53. A. L. Luz, C. D. Kassotis, H. M. Stapleton and J. N. Meyer, Toxicology, 393, 150, (2018).

54. Y. Liu and M. F. R. Khan, Crop Prot. 85, 33, (2016).

55. H. Jia, F. Bai, N. Liu, X. Liang, P. Zhan, C. Ma, X. Jiang and X. Liu, Eur. J. Med. Chem. 123, 202, (2016).

56. C. Han, Y. C. Guo, D. D. Wang, X. J. Dai, F. J. Wu, H. F. Liu, G. F. Dai and J. C. Tao, Chinese Chem. Lett. 26, 534, (2015).

57. M. D. J. Alam, O. Alam, S. A. Khan, M. J. Naim, M. Islamuddin and G. S. Deora, Drug Des. Dev. Ther. 10, 3529, (2016).

58. K. R. A. Abdellatif, H. A. H Elshemy and A. A. Azoz, Bioorg. Chem. 63, 13, (2015).

59. S. A. H. E. Feky, Z. K. A. E. Sami, N. A. Osman, J. Lashine, M. A. Kamel and H. K. Thabet, Bioorg. Chem. 58, 104, (2015).

60. S. N. Thore, S. V. Gupta and K. G. Baheti, J. Saudi. Chem. Soc. 20, 259, (2016).

61. Z. B. Wu, X. Zhou, Y. Q. Ye, P. Y. Wang and S. Yang, Chinese Chem. Lett. 28, 121, (2017).

62. W. Wang, L. P. Wang, B. K. Ning, M. Z. Map, C. Xue and H. Y. Wang, Phosphorus Sulfur Silicon, 191, 1362, (2016).

63. X. L. Deng, J. Xie, Y. Q. Li, D. K. Yuan, X. P. Hu, L. Zhang, Q. M. Wang, M. Chi and X. L. Yang, Chinese Chem. Lett. 27, 566, (2016).

64. X. H. Liu, W. Zhao, Z. H. Shen, J. H. Xing, J. Yuan, G. Yang, T. M. Xu, W. L. Peng, Bioorg. Med. Chem. Lett. 26, 3626, (2016).

65. X. H. Lv, Q. S. Li, Z. L. Ren, M. J. Chu, J. Sun, X. Zhang, M. Xing, H. L. Zhu and H. Q. Cao, Eur. J. Med. Chem. 108, 586, (2016).

66. E. Therrien, G. Larouche, N. Nguyen, J. Rahil, A. M. Lemieux, Z. Li, M. Fournel, T. P. Yan, A. J. Landry, S. Lefebvre, J. J. Wang, K. Macbeth, C. Heise, A. Nguyen, J. M. Besterman, R. Deziel and A. Wahhab, Bioorg. Med. Chem. Lett. 25, 2514, (2015).

67. M. A. Tabrizi, P. G. Baraldi, E. Ruggiero, G. Saponaro, S. Baraldi, R. Romagnoli, A. Martinelli and T. Tuccinardi, Eur. J. Med. Chem. 97, 289, (2015).

68. C. I. Nieto, M. P. Cabildo, M. P. Cornago, D. Sanz, R. M. Claramunt, I. Alkorta, J. Elguero, J. A. Garcia, A. Lopez and D. A. Castroviejo, J. Mol. Struct. 1100, 518, (2015).

69. E. Kick, R. Martin, Y. Xie, B. Flatt, E. Schweiger, T. L. Wang, B. Busch, M. Nyman, X. H. Gu, G. Yan, B. Wagner, M. Nanao, L. Nguyen, T. Stout, A. Plonowski, I. Schulman, J. Ostrowski, T. Kirchgessner, R. Wexler and R. Mohan, Bioorg. Med. Chem. Lett. 25, 372, (2015).

70. V. Deiana, M. G. Canas, M. R. Pazos, J. F. Ruiz, B. Asproni, E. Cichero, P. Fossa, E. Munoz, F. Deligia, G. Murineddu, M. G. Arencibia and G. A. Pinna, Eur. J. Med. Chem. 112, 66, (2016).

71. S. Shu, X. Cai, J. Li, Y. Feng, A. Dai, J. Wang, D. Yang, M. W. Wang and H. Liu, Bioorg. Med. Chem. 24, 2852, (2016). 